\title{
Development and Validated of Stability-Indicating RP-HPLC Method for the Analysis of Zolpidem Tartrate in Tablets
}

\author{
M. MATHRUSRI ANNAPURNA*, S. BHARGAVI, S. PAVANI and B. VENKATESH \\ Department of Pharmaceutical Analysis \& Quality Assurance, \\ GITAM Institute of Pharmacy, GITAM University, Visakhapatnam, India \\ mathrusri2000@yahoo.com
}

Received 31 January 2014 / Accepted 20 February 2014

\begin{abstract}
A validated stability-indicating high-performance liquid chromatographic technique was developed for the determination of Zolpidem tartrate in pharmaceutical dosage forms. Chromatographic separation was performed on Shimadzu Model CBM-20A/20 Alite, using water: methanol: acetic acid(25: $75: 0.1, \mathrm{v} / \mathrm{v})$ as mobile phase with a flow rate of $1.2 \mathrm{~mL} / \mathrm{min}$. Zolpidem tartrate was subjected to stress conditions (acidic, alkaline, oxidation, thermaland photolytic) and the method was validated as per ICH guidelines.
\end{abstract}

Keywords: Zolpidem tartrate, RP-HPLC, Stability-indicating, ICH

\section{Introduction}

Zolpidem tartrate (ZPT), chemically known as N, N, 6-Trimethyl-2-ptolyl-imidazo (1,2-a) pyridine-3-acetamide L-(+)-tartrate $(2: 1)$ (Figure 1) is an imidazo pyridine derivative, is a non-benzodiazepine hypnotic agent binds preferentially to one benzodiazepine receptor subtype $\omega$-1 bezodiazepine- 1 thought to mediate hypnotic effects ${ }^{1}$. This combines a rapid onset with a short duration of action. Zolpidem tartrate behaves as a sleep inducer without the muscle relaxant and anticonvulsant effects of the benzodiazepines. The hypnotic actions of Zolpidem, like benzodiazepine hypnotics, are mediated at the benzodiazepine recognition site of the GABAA receptor complex ${ }^{2-4}$. However, the neuro pharmacological profile of Zolpidem tartrate is somewhat different from that of most benzodiazepines ${ }^{5-6}$. Zolpidem binds with low affinity to a $\alpha 5$-containing GABAA-receptor subtypes ${ }^{7}$.

Literature survey revealed that Zolpidem tartrate was determined by liquid chromatographic methods ${ }^{8-19}, \mathrm{LC}^{-\mathrm{MS}^{20-21}}, \mathrm{GC}^{22-23}, \mathrm{GC}^{-\mathrm{MS}^{24}}$, capillary electrophoresis ${ }^{25}$, UV-Visible spectroscopy ${ }^{26-32}$ and HPTLC-LC ${ }^{33}$.

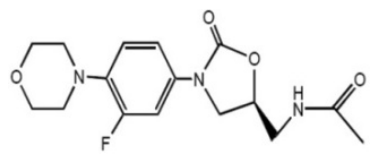

Figure 1. Chemical structure of Zolpidem tartrate (ZPT) 


\section{Experimental}

Analytical grade reagents were used. Zolpidem tartrate was supplied as gift sample from Dr. Reddy's Labs (India) India. Zolpidem tartrate (ZPT) stock was prepared by dissolving $25 \mathrm{mg}$ of the drug in $25 \mathrm{~mL}$ of methanol in a volumetric flask $(1000 \mu \mathrm{g} / \mathrm{mL})$ and working standard solutions were obtained by proper dilution of this stock solution with mobile phase.

Zolpidem tartrate (ZPT) is available commercially as tablets with brand names ZOLINOX $^{\circledR}$ (Ranbaxy Laboratories, India) (Label claim: $7.5 \mathrm{mg}$ ) and AMBIEN $^{\circledR}$ (Dr. Reddy's Laboratories, India) (Label claim: $10 \mathrm{mg}$ ) and twenty tablets from each brand were procured from the local market.

\section{Instrumentation}

Chromatographic separation was achieved by using C18 column $(250 \mathrm{~mm} \times 4.6 \mathrm{~mm}$ i.d., $5 \mu \mathrm{m}$ particle size) for HPLC system of Shimadzu Model CBM-20A/20 Alite, equipped with SPD M20A prominence photodiode array detector, maintained at $25^{\circ} \mathrm{C}$.

\section{Chromatographic conditions}

Isocratic elution was performed using water: methanol: acetic acid $(25: 75: 0.1, \% \mathrm{v} / \mathrm{v})$ as mobile phase. The overall run time was $10 \mathrm{~min}$. with flow rate $1.2 \mathrm{~mL} / \mathrm{min}$ with UV detection at $254 \mathrm{~nm} .20 \mu \mathrm{L}$ of sample was injected into the HPLC system.

\section{Preparation of stock and sample solution}

Zolpidem tartrate stock solution $(1000 \mu \mathrm{g} / \mathrm{mL})$ was prepared by weighing accurately $25 \mathrm{mg}$ of Zolpidem tartrate in a $25 \mathrm{~mL}$ volumetric flask with mobile phase. Working standard solutions were prepared on daily basis from the stock solution with mobile phase and filtered through $0.45 \mu \mathrm{m}$ membrane filter prior to injection.

\section{Method validation}

The method was validated for system suitability, linearity, limit of quantitation (LOQ), limit of detection (LOD), precision, accuracy, selectivity and robustness ${ }^{34}$.

\section{Linearity}

Linearity test solutions for the assay method were prepared from a stock solution at different concentration levels $(0.5-200 \mu \mathrm{g} / \mathrm{mL})$ of the assay analyte concentration and $20 \mu \mathrm{L}$ of each solution was injected in to the HPLC system and the peak area of the chromatogram obtained was noted. The calibration curve was plotted by taking the concentration on the $\mathrm{x}$-axis and the corresponding peak area on the y-axis. The data was treated with linear regression analysis method.

The limit of quantification and limit of detection were based on the standard deviation of the response and the slope of the constructed calibration curve, as described in ICH guidelines Q2 (R1) ${ }^{34}$.

\section{Precision study}

The intra-day precision of the assay method was evaluated by carrying out 3 independent assays of a test sample of Zolpidem tartrate at three concentration levels $(20,50$ and $100 \mu \mathrm{g} / \mathrm{mL})$ against a qualified reference standard. The \%RSD of three obtained assay values at three different concentration levels was calculated. The inter-day precision study was performed on three different days i.e. day 1 , day 2 and day 3 at three different concentration levels $(20$, 50 and $100 \mu \mathrm{g} / \mathrm{mL}$ ) and each value is the average of three determinations. The $\%$ RSD of three obtained assay values on three different days was calculated. 


\section{Accuracy study}

The accuracy of the assay method was evaluated in triplicate at three concentration levels $(80,100$ and 120\%) and the percentage recoveries were calculated. Standard addition and recovery experiments were conducted to determine the accuracy of the method for the quantification of Zolpidem tartrate in the drug product. The study was carried out in triplicate at 18,20 and $22 \mu \mathrm{g} / \mathrm{mL}$. The percentage recovery in each case was calculated.

\section{Robustness}

The robustness of the assay method was established by introducing small changes in the HPLC conditions which included wavelength $(252$ and $256 \mathrm{~nm})$, percentage of methanol in the mobile phase $(73$ and $77 \%)$ and flow rate $(1.1$ and $1.3 \mathrm{~mL} / \mathrm{min})$. Robustness of the method was studied using six replicates at a concentration level of $100 \mu \mathrm{g} / \mathrm{mL}$ of Zolpidem tartrate.

\section{Analysis of marketed formulations}

The content of 20 tablets of each brand was mixed and quantity equivalent to $25 \mathrm{mg}$ of drug weighed accurately and dissolved in mobile phase in a $25 \mathrm{~mL}$ volumetric flask, sonicated and filtered. The filtrate was diluted as per the requirement and $20 \mu \mathrm{L}$ solution of each of marketed formulations $\left(\right.$ ZOLINOX $^{\circledR}$ and AMBIEN $^{\circledR}$ ) was injected in to the HPLC system for conducting the assay.

\section{Forced degradation studies}

Forced degradation studies were performed to evaluate the stability indicating properties and specificity of the method ${ }^{35}$. All solutions for stress studies were prepared at an initial concentration of $1.0 \mathrm{mg} / \mathrm{mL}$ of Zolpidem tartrate and refluxed for 30 min at $80{ }^{\circ} \mathrm{C}$ and then diluted with mobile phase. $1.0 \mathrm{mg} / \mathrm{mL}$ Zolpidem tartrate solution was exposed to acidic degradation with $0.1 \mathrm{M} \mathrm{HCl}$ for $30 \mathrm{~min}$ at $80{ }^{\circ} \mathrm{C}$ the stressed sample was cooled, neutralized and diluted with mobile phase. Similarly stress studies were conducted in alkaline conditions with $0.01 \mathrm{M} \mathrm{NaOH}$ at $80{ }^{\circ} \mathrm{C}$ for $30 \mathrm{~min}$. and neutralized after cooling with proper dilution with mobile phase. Oxidative stress studies were performed using $30 \% \mathrm{H}_{2} \mathrm{O}_{2}$ and thermal stress studies were conducted in thermostat at $80{ }^{\circ} \mathrm{C}$ for $30 \mathrm{~min} .20 \mu \mathrm{L}$ solution of each of these solutions which were exposed to forced degradation studies were injected in to the HPLC system and the chromatograms were recorded.

\section{Results and Discussion}

Initially the stressed samples were analyzed using a mixture of water: methanol (50:50, v/v) with a flow rate of $1.0 \mathrm{~mL} / \mathrm{min}$ in which the peak symmetry was not satisfactory. The mobile composition was modified as 30: 70, v/v with flow rate $1.2 \mathrm{~mL} / \mathrm{min}$ where a broad peak was eluted with slight tailing. Finally the mobile phase composition was modified as water: methanol: acetic acid (25:75: $0.1, \mathrm{v} / \mathrm{v}$ ) with flow rate $1.2 \mathrm{~mL} / \mathrm{min}$ and a sharp peak was eluted at retention time $4.20 \pm 0.03 \mathrm{~min}$. (UV detection at $254 \mathrm{~nm}$ ) which was chosen as the best chromatographic response for the entire study.

Zolpidem tartrate shows linearity over a concentration range $0.5-200 \mu \mathrm{g} / \mathrm{mL}$ (Table 1) with $\%$ RSD $0.15-0.52$. The linear regression equation was found to be $y=65834 \mathrm{x}+8162\left(\mathrm{r}^{2}\right.$ $=0.9999$ ) (Figure 2). The LOQ was found to be $0.0729 \mu \mathrm{g} / \mathrm{mL}$ and the LOD was found to be $0.0221 \mu \mathrm{g} / \mathrm{mL}$. 
Table 1. Linearity of Zolpidem tartrate

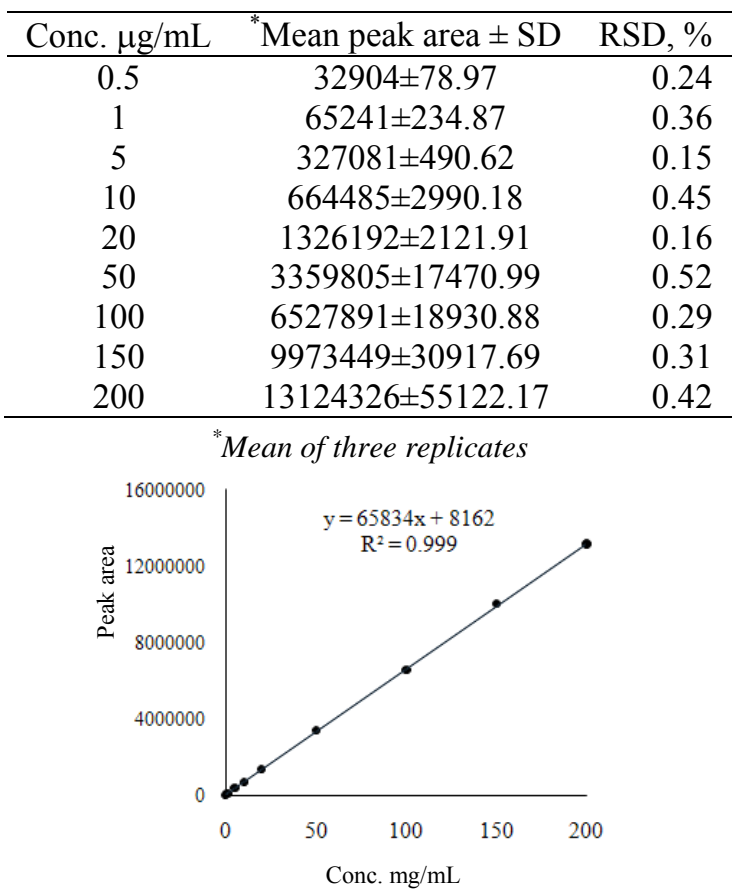

Figure 2. Calibration curve of Zolpidem tartrate

The representative chromatogram of Zolpidem tartrate was shown in Figure 3A. The proposed method was applied to the formulations and the percentage recovery was calculated as 99.74-99.81 (Table 2) without the interference from the excipients (Figure 3B and $3 \mathrm{C}$ ).

Table 2. Analysis of Zolpidem tartrate commercial formulation (Tablets)

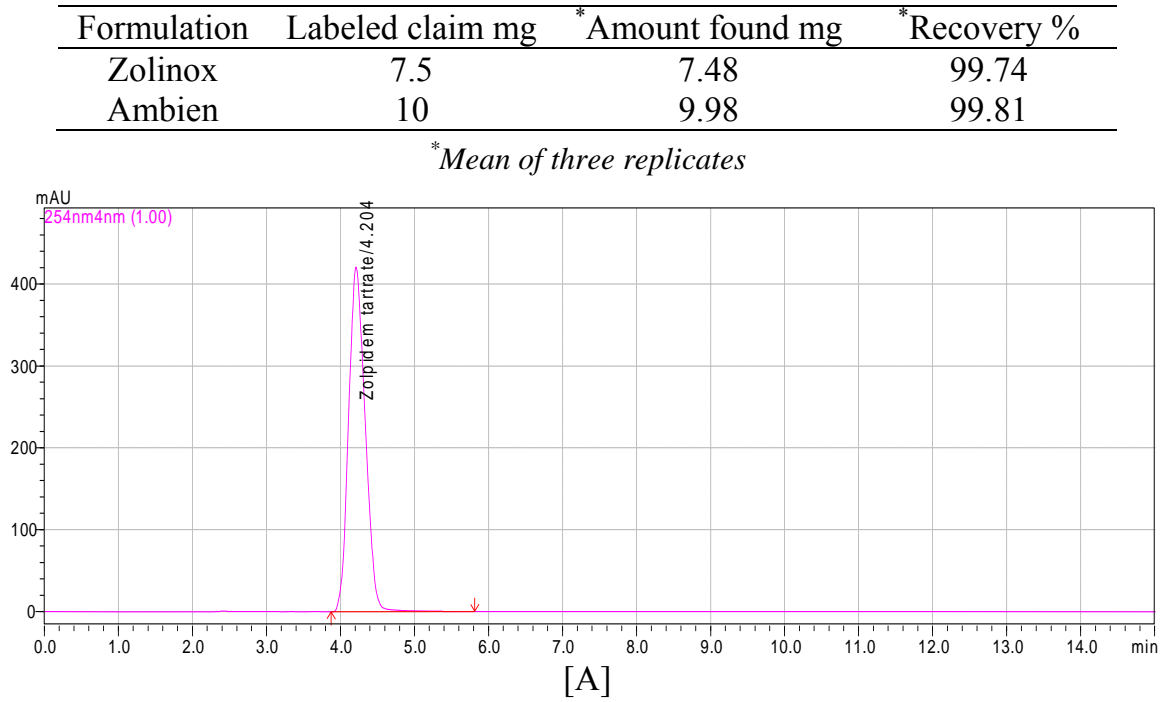




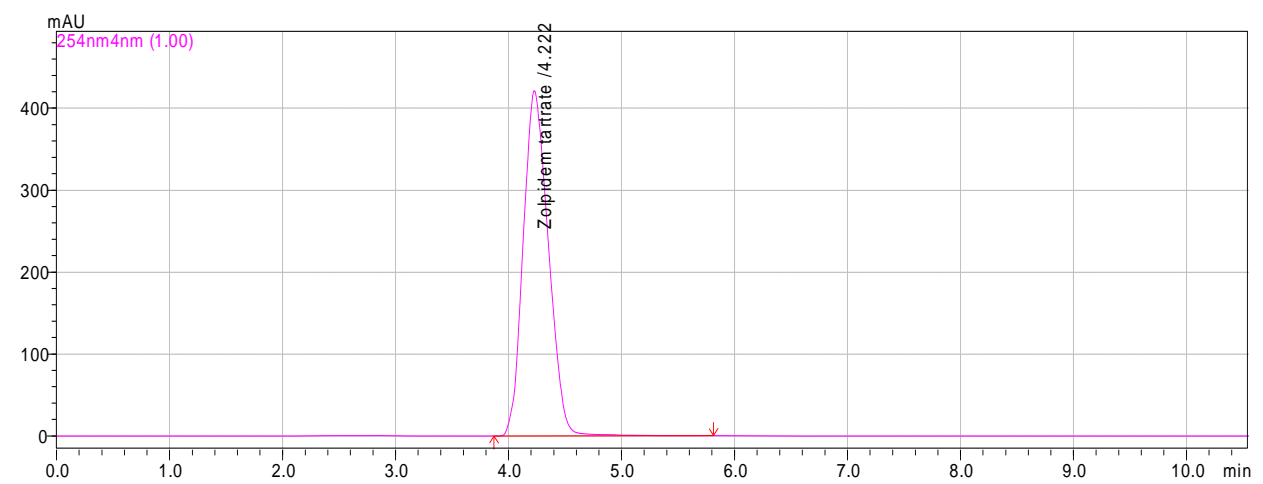

[B]

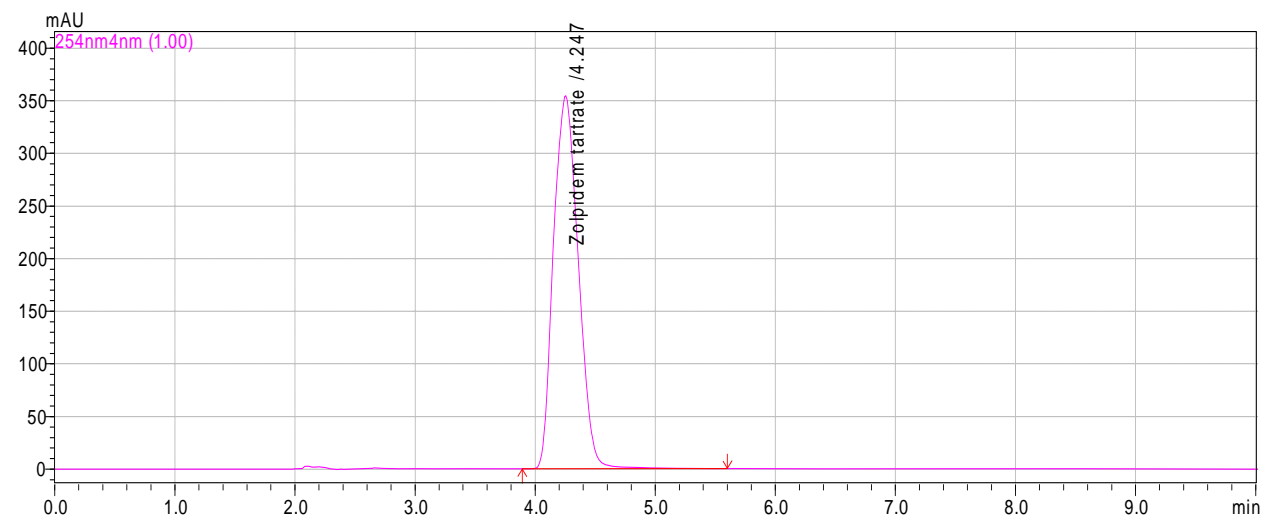

[C]

Figure 3. Typical chromatograms of Zolpidem tartrate $(100 \mu \mathrm{g} / \mathrm{mL})$ [A], ZOLINOX (Label claim: $7.5 \mathrm{mg}$ ) [B]AMBIEN (Label claim: $10 \mathrm{mg}$ ) [C]

The \% RSD in precision studies was found to be $0.10-0.37$ (Intra-day) and 0.12-0.63 (Inter-day) where as in accuracy studies it is $0.12-0.25$ with a recovery of $99.17-99.72$ (Table 3$)$ indicating that the method is precise and accurate $(\% \mathrm{RSD}<2.0)$. The $\%$ RSD was less than $2.0 \%(0.10-0.35)$ indicating that the proposed method is robust (Table 4$)$.

Table 3. Precision and accuracy studies of Zolpidem tartrate

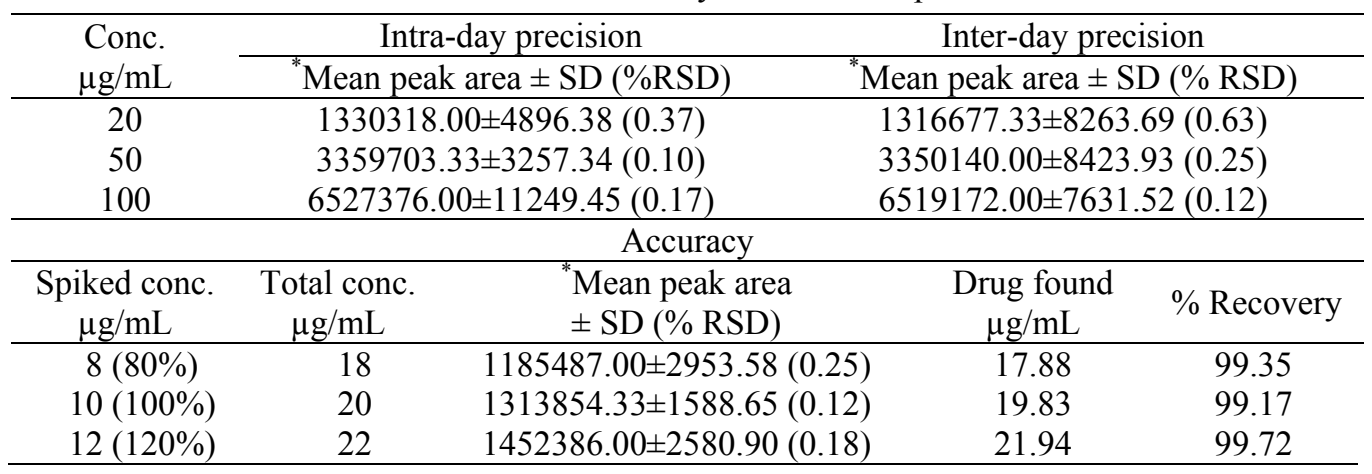

${ }^{*}$ Mean of three replicates 
Table 4. Robustness study of Zolpidem tartrate

\begin{tabular}{ccccc}
\hline Parameter & Condition & $\begin{array}{c}{ }^{*} \text { Mean } \\
\text { peak area }\end{array}$ & $\begin{array}{c}{ }^{*} \text { Mean peak area } \pm \text { SD } \\
(\% \mathrm{RSD})\end{array}$ & $\begin{array}{c}{ }^{*} \text { Assay } \\
\%\end{array}$ \\
\hline Flow rate & 1.1 & 6535288 & $6525191.33 \pm 11682.83$ & \\
$( \pm 0.1 \mathrm{~mL} / \mathrm{min})$ & 1.2 & 6527891 & $(0.18)$ & 99.96 \\
& 1.3 & 6512395 & & \\
Detection & 253 & 6502525 & $6521626.00 \pm 16887.93$ & 99.90 \\
wavelength & 254 & 6527891 & $(0.26)$ & \\
$( \pm 2 \mathrm{~nm})$ & 256 & 6534522 & & \\
Mobile phase & $23: 77$ & 6521590 & $6521501.00 \pm 6434.96$ & $(0.10)$ \\
composition & $25: 75$ & 6527891 & & \\
$( \pm 2 \%, \mathrm{v} / \mathrm{v})$ & $27: 73$ & 6515022 &
\end{tabular}

The stability indicating capability of the method was established from the separation of Zolpidem tartrate peak from the degraded samples. Zolpidem tartrate has shown $22.03 \%$ and $25.35 \%$ degradation during acidic and oxidative stress conditions indicating that the drug is sensitive where as in other degradations the drug has undergone decomposition slightly (< $20.0 \%$ ) (Table 5). Typical chromatograms obtained from the stressed samples were shown in Figure 4A-4E.

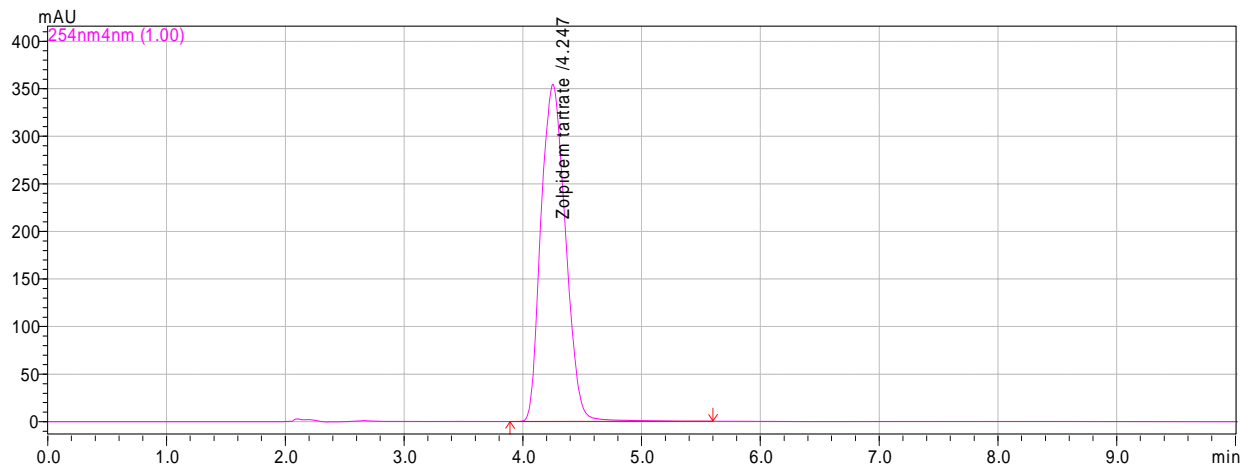

[A]

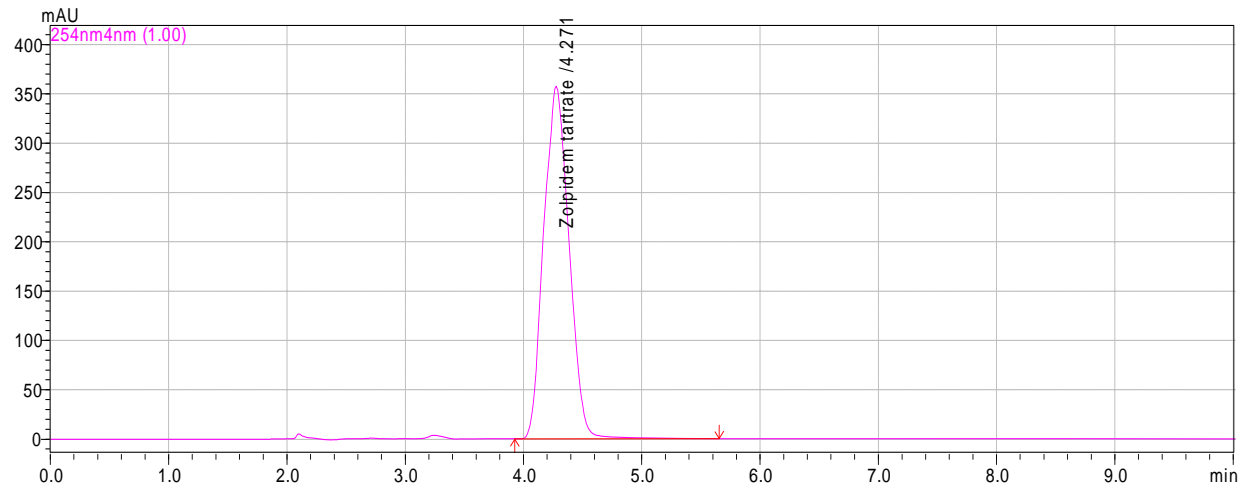

[B] 


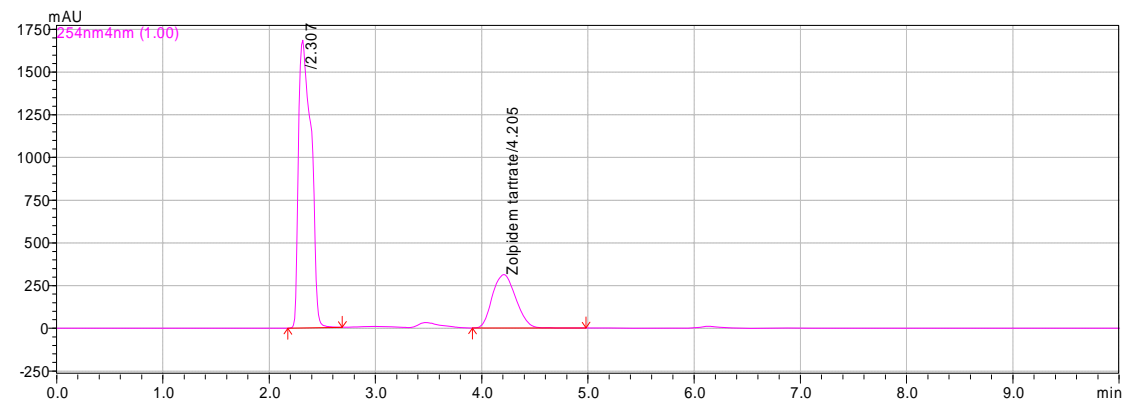

$[\mathrm{C}]$

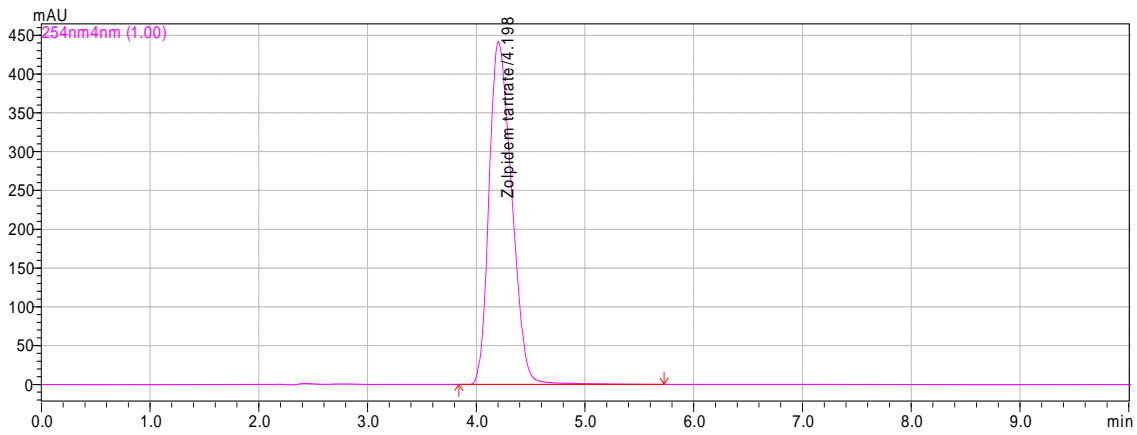

[D]

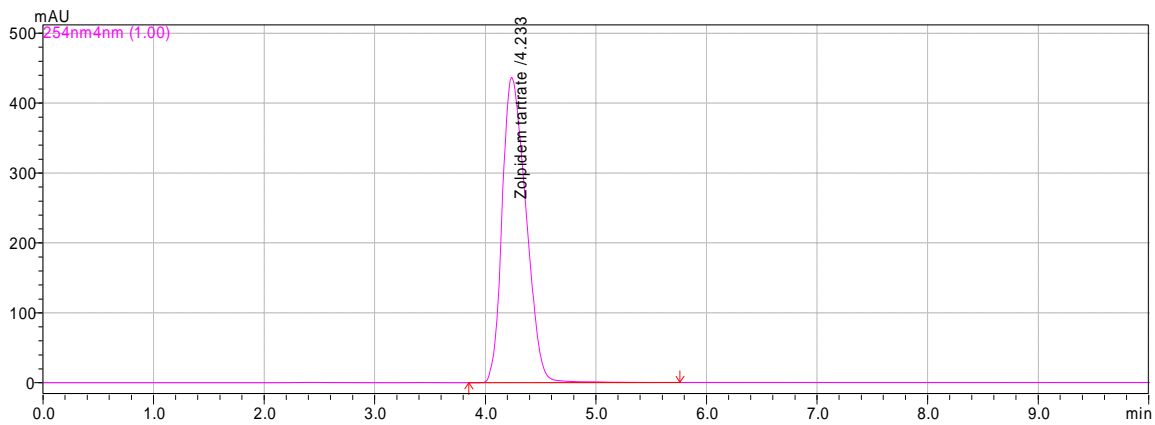

[E]

Figure 4. Typical chromatograms of Zolpidem tartrateon acidic [A] alkaline [B] oxidative [C] thermal [D] photolytic [E] degradation

Table 5. Forced degradation studies of Zolpidem tartrate

\begin{tabular}{cccc}
\hline Stress Conditions & $\begin{array}{c}{ }^{*} \text { Mean peak } \\
\text { area }\end{array}$ & $\begin{array}{c}{ }^{*} \text { Drug } \\
\text { recovered \% }\end{array}$ & $\begin{array}{c}{ }^{*} \text { Drug } \\
\text { decomposed \% }\end{array}$ \\
\hline Standard drug (Untreated) & 6545101 & 100 & - \\
Acidic degradation & 5103406 & 77.97 & 22.03 \\
Alkaline degradation & 5341037 & 81.60 & 18.40 \\
Oxidative degradation & 4886007 & 74.65 & 25.35 \\
Thermal degradation & 6378709 & 97.46 & 2.54 \\
Photolytic degradation & 6533255 & 99.82 & 0.18 \\
\hline
\end{tabular}

*Mean of three replicates 
The present stability-indicating method for the determination of Zolpidem tartrate in pharmaceutical formulations is specific because the drug peak was well separated even in the presence of degradation products. The system suitability parameters for the Zolpidem tartrate peak shows that the theoretical plates were more than 2000 and the tailing factor was less than 2 (or $<1.5-2.0$ ).

\section{Conclusion}

The proposed stability-indicating HPLC method was validated as per ICH guidelines and can be successfully applied to perform long-term and accelerated stability studies of Zolpidem tartrate formulations.

\section{Acknowledgement}

The authors are grateful to M/s GITAM University for providing necessary research facilities and to Dr. Reddy's Laboratories (India) for providing the gift samples of Zolpidem tartrate.

\section{References}

1. Budavari S, Editor. The Merck Index. $12^{\text {th }}$ Ed., White house Station (NJ): Merck and Co. Inc; 1996, p. 10322.

2. Walker R and Edwards C, Clinical Pharmacy and Therapeutics, $2^{\text {nd }}$ Ed. Churchill Livingstone United Kingdom; 1999, p. 399.

3. Haefely W E, Eur Arch Psychiatr Neurol Sci., 1989, 238(5-6), 294-301; DOI:10.1007/BF00449811

4. Sauvanet J P, Langer S Z and Morselli P L, Raven Press, New York, 1988, 175-181.

5. Arbilla S, Depoortere H, George P and Langer S, Arch Pharmacol., 1985, 330(3), 248-251.

6. Benavides J, Peny B, Du Bois A, Perrault G, Morel E, Zivkovic B and Scatton B, $J$ Pharmacol Exp Ther., 1988, 245(3), 1033-1041.

7. Besnard F, Avenet P, Itier V, Granger P, Partiséti M, Depoortere H, Graham D, Langer S Z, Freeman H, Puech A J and Roth T, Zolpidem: An Update of its Pharmacological Properties and Therapeutic Place in the Management of Insomnia. Elsevier; Paris, 1996, 21-32.

8. Laviana L, Mangas C, Fern'andez-Mar'1 F, Bayod M and Blanco D, J Pharm Biomed Anal., 2004, 36(4), 925-928; DOI:10.1016/j.jpba.2004.08.025

9. Paula R Ring and James M Bostick, J Pharm Biomed Anal., 2000, 22(3), 495-504; DOI:10.1016/S0731-7085(99)00311-8

10. Tracqui A, Kintz P and Mangin P, J Chromatogr B: Biomed Sci Appl., 1993, 616(1), 95-103; DOI:10.1016/0378-4347(93)80476-K

11. Ascalone V, Flaminio L, Guinebault P, Thenot J P and Morselli P L, J Chromatogr B: Biomed Sci Appl., 1992, 581(2), 237-250; DOI:10.1016/0378-4347(92)80277-W

12. Gock S B, Wong S H Y, Nuwayhid N, Venuti S E, Kelley P D, Teggatz J R and Jentzen J M, J Anal Toxicol., 1999, 23(26), 559-562; DOI:10.1093/jat/23.6.559

13. Ptáček P, Macek $\mathrm{J}$ and Klíma J, J Chromatogr B: Biomed Sci Appl., 1997, 694(2), 409-413; DOI:10.1016/S0378-4347(97)00119-9

14. Qiao Wang, Lei Sun and Chyan E Lau, J Chromatogr B Biomed Sci Appl., 1999, 734(2), 299-305; DOI:10.1016/S0378-4347(99)00376-X

15. Guinebault P, Dubruc C, Hermann P and Thénot J P, J Chromatogr B: Biomed Sci Appl., 1986, 383, 206-211; DOI:10.1016/S0378-4347(00)83462-3 
16. Pushpalatha P, Sarin R K, Rao M A, Rao T R, Baggi M and Satish Varma, J Pharm Allied Sci., 2012, 9(2).

17. Konoz E, Mohsen Sarrafi A H, Abdolahnejad R and Bahrami-Zonoz M, J Chem., Article ID 357890, 6 pages, 2013; DOI:10.1155/2013/357890

18. Mahajan M P and Sawant S D, J Pharmacy Res., 2011, 4(10), 3789-3791.

19. Yohan K, Narasimha Rao D, Prasada Rao M, Sudheer Kumar A and Sivashankar R B, World J Pharm Pharm Sci., 2013, 2(5), 3423-3435.

20. Kintz P, Villain $M$ and Ludes B, J Chromatogr B, 2004, 811(1), 59-63; DOI:10.1016/j.jchromb.2004.03.074

21. Giroud C, Augsburger M, Menetrey A and Mangin P, J Chromatogr B, 2003, 789(1), 131-138; DOI:10.1016/S1570-0232(03)00135-1

22. Gaillard Y, Gay-Montchamp J P and Ollagnier M, J Chromatogr., 1993, 622(2), 197-208; DOI:10.1016/0378-4347(93)80266-7

23. Stanke F, Jourdil N, Bessard J and Bessard G, J Chromatogr B: Biomed Sci Appl., 1996, 675(1), 43-51; DOI:10.1016/0378-4347(95)00311-8

24. Keller T, Schneider A and Tutsch-Bauer E, Forensic Sci Int., 1999, 106(2), 103-108; DOI:10.1016/S0379-0738(99)00185-1

25. Hempel G and Blaschke G, J Chromatogr B: Biomed Sci Appl., 1996, 675(1), 131-137; DOI:10.1016/0378-4347(95)00342-8

26. Patil K S, Pore Y V and Bhise S B, J Pharm Sci Res., 2010, 2(1), 1-4

27. Rajiv Chomwal, Amit Kumar and Anju Goyal. J Pharm Bioall Sci., 2010, 2(4), 365-368.

28. Mathrusri Annapurna M, Sai Pavan Kumar B, Venkatesh B and Raj Prakash J, Int J Res Pharm Biomed Sci., 2012, 3(3), 1220-1226.

29. Mathrusri Annapurna M, Sai Pavan Kumar B, Venkatesh B and Raj Prakash J, Chem Sci Trans., 2012, 1(3), 560-565; DOI:10.7598/cst2012.226

30. Mathrusri Annapurna M, Swathi B, Siri Chandra M and Tulasi K, J Appl Pharm Sci., 2012, 2(11), 96-99.

31. Rubesh Kumar S, Hima Sai Bindu N, Hima V, Subhahan Bee D, Duganath N, Bharath Ratna Kumar P and Devanna N, Der Pharmacia Sinica, 2013, 4(1), 21-28.

32. Mathrusri Annapurna M, Bhargavi S and Anusha S, Drug Invention Today, 2012, 4(12), 663-666.

33. El Zeany B A, Moustafa A A and Farid N F, J Pharm Biomed Anal., 2003, 33(3), 393-401; DOI:10.1016/S0731-7085(03)00243-7

34. International Conference on Harmonization of Technical Requirements for the Registration of Pharmaceutical for Human Use: Validation of Analytical procedures, Text and methodology - Q2 (R1), 2005.

35. ICH Stability Testing of New Drug Substances and Products Q1A (R2), International Conference on Harmonization, 2003. 